\title{
Floristic and Structural Composition of Natural Regeneration in a Subtropical Atlantic Forest
}

\author{
Fábio Pastório ${ }^{1}$, Hanna Bloemer ${ }^{1}$, André de Gasper ${ }^{1}$ \\ ${ }^{1}$ Universidade Regional de Blumenau - FURB, Blumenau/SC, Brasil
}

\begin{abstract}
Understanding the regeneration process in an old growth forest is essential for restoration projects. The present research sought to characterize the floristic and structural composition of shrub-tree species in São Francisco de Assis Municipal Park in Blumenau-SC. We sampled 50 permanent plots divided into three height classes. We estimated the total natural regeneration index for each species, the Shannon-Wiener diversity index and Pielou equability, and classified the species according to life-form and ecological group. A total of 1048 individuals were found, distributed in 112 species, 69 genera and 37 families. The species with the highest values of total natural regeneration index were Rudgea recurva, $R$. jasminoides, Ouratea parviflora, Psychotria nuda and Virola bicuhyba. The Shannon and Pielou indices demonstrated high diversity and equability for the natural regeneration area sampled. The results indicate species possibly capable of reaching the tree strata, and also indicate high forest conservation.
\end{abstract}

Keywords: diversity, phytosociology, shrubs. 


\section{INTRODUCTION AND OBJECTIVES}

The Atlantic Rainforest originally occupied an area of approximately 150 million ha, representing one of the largest tropical forests in the Americas, with high biological diversity and endemism, reflecting the high heterogeneity of habitats related to the significant altitudinal, latitudinal and longitudinal range of the region (Ribeiro et al., 2009). However, the forest cover that was previously continuous is now fragmented into small forest remnants, consisting of only $11.7 \%$ of the original vegetation cover, and with about $83 \%$ of these remnants being smaller than 50 ha (Metzger, 2000; Ribeiro et al., 2009).

The subtropical Atlantic Rainforest has a low percentage of conservation units (about $3 \%$ of the total area), and a high degree of degradation. Therefore, there is an urgent need to preserve forest remnants that present significant native species variety (MMA, 2007), many of them still unknown to science. Therefore, for the implementation of strategies and management plans, it is necessary to acquire information about the ecology of native species, considered essential to aid in public decision making and conservation measures (Hanazaki, 2003; Pinto et al., 2006).

In this sense, an important forest ecosystem process is the natural regeneration of plant species. Natural regeneration is mainly represented by three mechanisms: seed rain, dormant seed bank, and seedling bank on the forest floor. These mechanisms are responsible for the reconstruction and establishment of plant populations and determine, in part, the course of forest succession, structure and physiognomy (Garwood, 1989; Narvaes et al., 2008). Natural regeneration itself refers to the seedling bank in the forest understory (Araújo et al., 2004), and consists of a recruitment mechanism for adult individuals from the development of the bank of regenerating individuals in the understory. Additionally, the environmental conditions of the forest, such as light, water and nutrient availability, competition, pathogens and herbivores are determining factors in this process (Fenner \& Thompson, 2005). The way that each species responds to such factors, reflects on the success of recruitment (Melo, 2004).

Understanding natural regeneration is fundamental for silvicultural planning with maximum yield, elaboration of degraded area recovery programs and management plans in Conservation Units, as well as to provide indicative information on the current state of the forest in question and forecasts on their behavior and development (Amador \& Viana, 2000; IBAMA, 2002; Schorn \& Galvão, 2006).

This study was developed in order to provide scientific knowledge for the conservation and management of biodiversity threatened by anthropic action, especially the Atlantic Forest. The objective was to research the floristic and structural composition of the natural regeneration component in the São Francisco de Assis Municipal Natural Park, located in Blumenau, Santa Catarina.

\section{MATERIAL AND METHODS}

\subsection{Study area}

The study area comprises the São Francisco de Assis Municipal Natural Park (SFAMNP), located in the center of Blumenau, Santa Catarina (26 55' 18.9" S and $\left.49^{\circ} 04^{\prime} 18.9^{\prime \prime} \mathrm{W}\right)$. The PNMSFA covers 23 ha, with an altitude varying from 35 to $135 \mathrm{~m}$, and surrounded by an environmental protection area of $43 \mathrm{ha}$. The climate is $\mathrm{Cfa}$, humid temperate with hot summers (mesothermic), with an average temperature of $18^{\circ} \mathrm{C}$ in the coldest month and above $22^{\circ} \mathrm{C}$ in the hottest month, without a dry season (Koeppen, 1948).

The forest type is lowland subtropical rainforest, and the area is a region of rugged relief valley with steep slopes and a stream running through it. The land use history includes clear and selective logging of the forest and soil use for agriculture. With more than 50 years without exploitation, there is predominance of forest in advanced secondary stage and small patches of secondary vegetation in intermediate stage (Sevegnani, 2003).

\subsection{Data collection}

To characterize the natural regeneration, we established 50 permanent plots of $5 \times 5 \mathrm{~m}$, equivalent to $1,250 \mathrm{~m}^{2}$. The sub-bush, shrub, treelet, palm and tree individuals with height $\geq 30 \mathrm{~cm}$ and $\mathrm{DHB} \leq 5 \mathrm{~cm}$ located within the plots were marked and counted. The individuals sampled were classified into three height classes: $\mathrm{C} 1$ (from $30 \mathrm{~cm}$ to $60 \mathrm{~cm}$ in height); $\mathrm{C} 2$ (from $61 \mathrm{~cm}$ to $1.50 \mathrm{~m}$ in height) and C3 (from $1.51 \mathrm{~m}$ 
in height to $5 \mathrm{~cm}$ of DHB). Data collection occurred between November 2015 and February 2016.

Within each $5 \times 5 \mathrm{~m}$ plot, a 3 × $3 \mathrm{~m}$ subplot was demarcated, totaling 50 subplots, to adjust the size of the sampling area according to the proposed height classes. Thus, in the $3 \times 3 \mathrm{~m}$ subplots, individuals of class $1(\mathrm{C} 1)$ and 2 (C2) were sampled, while individuals of class 3 (C3) were sampled in the $5 \times 5 \mathrm{~m}$ plots. With the subplots of $3 \times 3 \mathrm{~m}$, there was a total of $1,700 \mathrm{~m}^{2}$ of sample area of the regeneration component. The effective sample plots were: 46 (C1), 47 (C2) and 50 (C3), since there was no individual in a few sample plots in $\mathrm{C} 1$ and $\mathrm{C} 2$.

We identified the plants in the field whenever possible, collecting those unidentified to undertake the identification process in the Roberto Miguel Klein Herbarium (FURB), located at Universidade Regional de Blumenau (FURB).

\subsection{Statistical analyses}

A rarefaction curve, with 1000 permutations, was constructed for each class in R, version 2.15.3 (R Development Core Team, 2017), using the vegan package. For the estimation of natural regeneration index (NRI), we calculated the distribution (frequency) and abundance (density) for each height class of each species sampled in the plots, using these indexes proposed by Finol (1971) and modified by Volpato (1994).
Shannon-Wiener (H') and Pielou (J') diversity indexes were calculated based on Magurran (1988), relating the proportional abundance of the species to the specific diversity. These calculations were performed in $\mathrm{R}$.

We classified the species into ecological groups applying the classification used by the Floristic and Forest Inventory of Santa Catarina (IFFSC) (Lingner et al., 2013): pioneer (P), secondary (SE) and climax (C). Similarly, the species life-forms were classified according to the classification used by IFFSC (Lingner et al., 2013). A species was considered threatened when listed in the Red Book of Brazilian Flora (Martinelli \& Moraes, 2013).

\section{RESULTS}

\subsection{Floristic composition}

We sampled 1048 individuals (13 of these dead), distributed in 112 species, 69 genera and 37 families (Table 1). The families with greatest species richness were Myrtaceae (22 spp.), Rubiaceae (15), Lauraceae (10), Melastomataceae (7), and Fabaceae (7), representing $58.93 \%$ of the total sampled species (Figure 1). The genera with the highest number of species were Psychotria L. (8 spp.), Eugenia L. (6) and Miconia Ruiz \& Pav., Ocotea Aubl. and Piper L. (5).

Table 1. Natural Regeneration Index (NRI) of species for each class in natural regeneration component at SFAMNP, Blumenau/SC.

\begin{tabular}{|c|c|c|c|c|c|c|c|c|c|c|}
\hline \multirow{2}{*}{ Species } & \multicolumn{3}{|c|}{ Class 1} & \multicolumn{3}{|c|}{ Class 2} & \multicolumn{3}{|c|}{ Class 3} & \multirow{2}{*}{ NRI } \\
\hline & RD1 & RF1 & NRI1 & RD2 & RF2 & NRI2 & RD3 & RF3 & NRI3 & \\
\hline Rudgea recurva & 15.81 & 10.80 & 13.30 & 9.71 & 7.44 & 8.58 & 16.25 & 7.67 & 11.96 & 11.28 \\
\hline Rudgea jasminoides & 7.26 & 5.68 & 6.47 & 8.99 & 8.37 & 8.68 & 8.03 & 6.82 & 7.42 & 7.53 \\
\hline Psychotria nuda & 4.27 & 3.98 & 4.13 & 5.04 & 6.05 & 5.54 & 7.46 & 6.25 & 6.85 & 5.51 \\
\hline Ouratea parviflora & 2.56 & 3.41 & 2.99 & 5.04 & 5.58 & 5.31 & 6.88 & 5.68 & 6.28 & 4.86 \\
\hline Marlierea tomentosa & 1.28 & 1.70 & 1.49 & 6.83 & 5.12 & 5.98 & 4.97 & 4.55 & 4.76 & 4.08 \\
\hline Virola bicuhyba & 5.56 & 5.68 & 5.62 & 3.24 & 3.72 & 3.48 & 2.29 & 2.84 & 2.57 & 3.89 \\
\hline Mollinedia schottiana & 2.99 & 3.41 & 3.20 & 3.24 & 3.26 & 3.25 & 3.63 & 4.26 & 3.95 & 3.46 \\
\hline Sorocea bonplandii & 2.14 & 2.27 & 2.20 & 5.76 & 5.58 & 5.67 & 1.91 & 2.27 & 2.09 & 3.32 \\
\hline Dendropanax australis & 2.99 & 3.41 & 3.20 & 3.24 & 2.79 & 3.01 & 3.44 & 3.98 & 3.71 & 3.31 \\
\hline Margaritopsis astrellantha & 4.70 & 4.55 & 4.62 & 3.96 & 3.26 & 3.61 & 0.00 & 0.00 & 0.00 & 2.74 \\
\hline Actinostemon concolor & 1.28 & 1.70 & 1.49 & 3.60 & 3.26 & 3.43 & 2.68 & 2.84 & 2.76 & 2.56 \\
\hline Garcinia gardneriana & 1.28 & 1.14 & 1.21 & 1.80 & 1.86 & 1.83 & 3.44 & 2.84 & 3.14 & 2.06 \\
\hline
\end{tabular}

$\mathrm{RD} 1$ = relative density for Class 1 ; RF1 = relative frequency for Class 1 ; NRI1 = Natural Regeneration Index for Class 1 ; RD2 = relative density for Class 2; RF2 = relative frequency for Class 2; NRI2 = Natural Regeneration Index for Class 2; RD3 = relative density for Class 3; RF3 = relative frequency for Class 3; NRI3 = Natural Regeneration Index for Class 3; NRI = total Natural Regeneration Index. ${ }^{*}$ threatened species according to Martinelli \& Moraes (2013); ${ }^{* *}$ exotic species. 
Table 1. Continued...

\begin{tabular}{|c|c|c|c|c|c|c|c|c|c|c|}
\hline \multirow{2}{*}{ Species } & \multicolumn{3}{|c|}{ Class 1} & \multicolumn{3}{|c|}{ Class 2} & \multicolumn{3}{|c|}{ Class 3} & \multirow{2}{*}{ NRI } \\
\hline & RD1 & RF1 & NRI1 & RD2 & RF2 & NRI2 & RD3 & RF3 & NRI3 & \\
\hline Sloanea guianensis & 2.56 & 3.41 & 2.99 & 0.72 & 0.93 & 0.82 & 1.53 & 1.99 & 1.76 & 1.86 \\
\hline Psychotria brachypoda & 1.71 & 1.14 & 1.42 & 3.60 & 1.86 & 2.73 & 1.15 & 1.14 & 1.14 & 1.76 \\
\hline Guapira opposita & 1.71 & 2.27 & 1.99 & 1.44 & 1.86 & 1.65 & 1.15 & 1.70 & 1.43 & 1.69 \\
\hline Justicia brasiliana & 5.98 & 3.41 & 4.70 & 0.00 & 0.00 & 0.00 & 0.00 & 0.00 & 0.00 & 1.57 \\
\hline Pausandra morisiana & 0.43 & 0.57 & 0.50 & 0.72 & 0.93 & 0.82 & 3.63 & 2.84 & 3.24 & 1.52 \\
\hline Trichilia casaretti & 0.00 & 0.00 & 0.00 & 1.08 & 1.40 & 1.24 & 3.06 & 3.41 & 3.23 & 1.49 \\
\hline Ocotea teleiandra & 0.43 & 0.57 & 0.50 & 1.08 & 1.40 & 1.24 & 1.72 & 1.99 & 1.85 & 1.20 \\
\hline Marlierea obscura & 0.43 & 0.57 & 0.50 & 2.16 & 2.33 & 2.24 & 0.57 & 0.85 & 0.71 & 1.15 \\
\hline Guarea macrophylla & 0.00 & 0.00 & 0.00 & 1.44 & 1.86 & 1.65 & 1.72 & 1.70 & 1.71 & 1.12 \\
\hline Hirtella hebeclada & 1.28 & 1.70 & 1.49 & 1.08 & 0.93 & 1.00 & 0.38 & 0.57 & 0.48 & 0.99 \\
\hline Psychotria suterella & 0.43 & 0.57 & 0.50 & 0.36 & 0.47 & 0.41 & 1.53 & 1.99 & 1.76 & 0.89 \\
\hline Myrcia pubipetala & 0.43 & 0.57 & 0.50 & 1.44 & 1.86 & 1.65 & 0.38 & 0.57 & 0.48 & 0.87 \\
\hline Sebastiania argutidens & 0.43 & 0.57 & 0.50 & 0.36 & 0.47 & 0.41 & 1.34 & 1.99 & 1.66 & 0.86 \\
\hline Protium kleinii & 2.14 & 1.70 & 1.92 & 0.36 & 0.47 & 0.41 & 0.19 & 0.28 & 0.24 & 0.86 \\
\hline Euterpe edulis & 1.28 & 1.70 & 1.49 & 0.72 & 0.93 & 0.82 & 0.19 & 0.28 & 0.24 & 0.85 \\
\hline Myrcia spectabilis & 0.43 & 0.57 & 0.50 & 0.36 & 0.47 & 0.41 & 1.53 & 1.70 & 1.62 & 0.84 \\
\hline Eugenia cerasiflora & 0.43 & 0.57 & 0.50 & 1.44 & 1.40 & 1.42 & 0.38 & 0.57 & 0.48 & 0.80 \\
\hline Leandra dubia & 1.71 & 0.57 & 1.14 & 1.44 & 0.47 & 0.95 & 0.19 & 0.28 & 0.24 & 0.78 \\
\hline Neomitranthes glomerata & 0.43 & 0.57 & 0.50 & 0.72 & 0.93 & 0.82 & 0.76 & 1.14 & 0.95 & 0.76 \\
\hline Calyptranthes strigipes & 0.43 & 0.57 & 0.50 & 1.08 & 0.93 & 1.00 & 0.57 & 0.85 & 0.71 & 0.74 \\
\hline Heisteria silvianii & 0.43 & 0.57 & 0.50 & 1.44 & 1.40 & 1.42 & 0.19 & 0.28 & 0.24 & 0.72 \\
\hline Pera glabrata & 0.00 & 0.00 & 0.00 & 0.36 & 0.47 & 0.41 & 1.34 & 1.99 & 1.66 & 0.69 \\
\hline Eugenia cereja* & 1.28 & 1.70 & 1.49 & 0.36 & 0.47 & 0.41 & 0.00 & 0.00 & 0.00 & 0.64 \\
\hline Quiina glaziovii & 0.85 & 1.14 & 1.00 & 0.36 & 0.47 & 0.41 & 0.38 & 0.57 & 0.48 & 0.63 \\
\hline Stylogyne pauciflora & 1.28 & 1.70 & 1.49 & 0.00 & 0.00 & 0.00 & 0.19 & 0.28 & 0.24 & 0.58 \\
\hline Nectandra oppositifolia & 1.28 & 1.70 & 1.49 & 0.00 & 0.00 & 0.00 & 0.19 & 0.28 & 0.24 & 0.58 \\
\hline Pourouma guianensis & 0.85 & 1.14 & 1.00 & 0.36 & 0.47 & 0.41 & 0.19 & 0.28 & 0.24 & 0.55 \\
\hline Mollinedia triflora & 0.43 & 0.57 & 0.50 & 0.36 & 0.47 & 0.41 & 0.57 & 0.85 & 0.71 & 0.54 \\
\hline Brosimum lactescens ${ }^{*}$ & 0.43 & 0.57 & 0.50 & 0.36 & 0.47 & 0.41 & 0.57 & 0.85 & 0.71 & 0.54 \\
\hline Bunchosia marítima & 0.85 & 1.14 & 1.00 & 0.72 & 0.47 & 0.59 & 0.00 & 0.00 & 0.00 & 0.53 \\
\hline Ocotea dispersa & 0.43 & 0.57 & 0.50 & 0.72 & 0.93 & 0.82 & 0.19 & 0.28 & 0.24 & 0.52 \\
\hline Inga striata & 0.00 & 0.00 & 0.00 & 0.72 & 0.93 & 0.82 & 0.57 & 0.85 & 0.71 & 0.51 \\
\hline Myrceugenia myrcioides & 0.00 & 0.00 & 0.00 & 1.08 & 0.93 & 1.00 & 0.38 & 0.57 & 0.48 & 0.49 \\
\hline Piper solmsianum & 0.85 & 1.14 & 1.00 & 0.00 & 0.00 & 0.00 & 0.38 & 0.57 & 0.48 & 0.49 \\
\hline Plinia cordifolia* & 0.00 & 0.00 & 0.00 & 0.36 & 0.47 & 0.41 & 0.96 & 1.14 & 1.05 & 0.49 \\
\hline Eugenia burkartiana* & 1.28 & 1.14 & 1.21 & 0.00 & 0.00 & 0.00 & 0.19 & 0.28 & 0.24 & 0.48 \\
\hline Miconia cabucu & 0.00 & 0.00 & 0.00 & 0.36 & 0.47 & 0.41 & 0.76 & 1.14 & 0.95 & 0.45 \\
\hline Sebastiania brasiliensis & 0.00 & 0.00 & 0.00 & 0.72 & 0.93 & 0.82 & 0.38 & 0.57 & 0.48 & 0.43 \\
\hline Aiouea saligna & 0.00 & 0.00 & 0.00 & 0.36 & 0.47 & 0.41 & 0.57 & 0.85 & 0.71 & 0.38 \\
\hline Ocotea catharinensis ${ }^{*}$ & 0.00 & 0.00 & 0.00 & 0.36 & 0.47 & 0.41 & 0.57 & 0.85 & 0.71 & 0.38 \\
\hline Piper cernuum & 0.43 & 0.57 & 0.50 & 0.00 & 0.00 & 0.00 & 0.57 & 0.57 & 0.57 & 0.36 \\
\hline Trichilia silvatica & 0.00 & 0.00 & 0.00 & 0.72 & 0.93 & 0.82 & 0.19 & 0.28 & 0.24 & 0.35 \\
\hline Magnolia ovata* & 0.00 & 0.00 & 0.00 & 0.72 & 0.93 & 0.82 & 0.19 & 0.28 & 0.24 & 0.35 \\
\hline
\end{tabular}

$\mathrm{RD} 1$ = relative density for Class $1 ; \mathrm{RF} 1=$ relative frequency for Class $1 ; \mathrm{NRI} 1=$ Natural Regeneration Index for Class $1 ; \mathrm{RD} 2=$ relative density for Class 2; RF2 = relative frequency for Class 2; NRI2 = Natural Regeneration Index for Class 2; RD3 = relative density for Class 3; RF3 = relative frequency for Class 3; NRI3 = Natural Regeneration Index for Class 3; NRI = total Natural Regeneration Index. ${ }^{*}$ threatened species according to Martinelli \& Moraes (2013); ${ }^{* *}$ exotic species. 
Table 1. Continued...

\begin{tabular}{|c|c|c|c|c|c|c|c|c|c|c|}
\hline \multirow{2}{*}{ Species } & \multicolumn{3}{|c|}{ Class 1} & \multicolumn{3}{|c|}{ Class 2} & \multicolumn{3}{|c|}{ Class 3} & \multirow{2}{*}{ NRI } \\
\hline & RD1 & RF1 & NRI1 & RD2 & RF2 & NRI2 & RD3 & RF3 & NRI3 & \\
\hline Seguieria langsdorffii* & 0.85 & 1.14 & 1.00 & 0.00 & 0.00 & 0.00 & 0.00 & 0.00 & 0.00 & 0.33 \\
\hline Piper ulei & 0.85 & 1.14 & 1.00 & 0.00 & 0.00 & 0.00 & 0.00 & 0.00 & 0.00 & 0.33 \\
\hline Ocotea odorifera ${ }^{*}$ & 0.43 & 0.57 & 0.50 & 0.36 & 0.47 & 0.41 & 0.00 & 0.00 & 0.00 & 0.30 \\
\hline Piper caldense & 0.00 & 0.00 & 0.00 & 0.72 & 0.93 & 0.82 & 0.00 & 0.00 & 0.00 & 0.27 \\
\hline Trichilia pseudostipularis & 0.43 & 0.57 & 0.50 & 0.00 & 0.00 & 0.00 & 0.19 & 0.28 & 0.24 & 0.25 \\
\hline Psychotria officinalis & 0.43 & 0.57 & 0.50 & 0.00 & 0.00 & 0.00 & 0.19 & 0.28 & 0.24 & 0.25 \\
\hline Aphelandra chamissoniana & 0.85 & 0.57 & 0.71 & 0.00 & 0.00 & 0.00 & 0.00 & 0.00 & 0.00 & 0.24 \\
\hline Piper miquelianum & 0.85 & 0.57 & 0.71 & 0.00 & 0.00 & 0.00 & 0.00 & 0.00 & 0.00 & 0.24 \\
\hline Xylopia brasiliensis & 0.00 & 0.00 & 0.00 & 0.36 & 0.47 & 0.41 & 0.19 & 0.28 & 0.24 & 0.22 \\
\hline Hieronyma alchorneoides & 0.00 & 0.00 & 0.00 & 0.36 & 0.47 & 0.41 & 0.19 & 0.28 & 0.24 & 0.22 \\
\hline Inga marginata & 0.43 & 0.57 & 0.50 & 0.00 & 0.00 & 0.00 & 0.00 & 0.00 & 0.00 & 0.17 \\
\hline Dahlstedtia cf. pentaphylla & 0.43 & 0.57 & 0.50 & 0.00 & 0.00 & 0.00 & 0.00 & 0.00 & 0.00 & 0.17 \\
\hline Eugenia melanogyna & 0.43 & 0.57 & 0.50 & 0.00 & 0.00 & 0.00 & 0.00 & 0.00 & 0.00 & 0.17 \\
\hline Myrcia selloi & 0.43 & 0.57 & 0.50 & 0.00 & 0.00 & 0.00 & 0.00 & 0.00 & 0.00 & 0.17 \\
\hline Eugenia beaurepairiana & 0.43 & 0.57 & 0.50 & 0.00 & 0.00 & 0.00 & 0.00 & 0.00 & 0.00 & 0.17 \\
\hline Eugenia brevistyla* & 0.43 & 0.57 & 0.50 & 0.00 & 0.00 & 0.00 & 0.00 & 0.00 & 0.00 & 0.17 \\
\hline Matayba intermedia & 0.43 & 0.57 & 0.50 & 0.00 & 0.00 & 0.00 & 0.00 & 0.00 & 0.00 & 0.17 \\
\hline Dahlstedtia cf. pinnata & 0.43 & 0.57 & 0.50 & 0.00 & 0.00 & 0.00 & 0.00 & 0.00 & 0.00 & 0.17 \\
\hline Miconia tristis & 0.43 & 0.57 & 0.50 & 0.00 & 0.00 & 0.00 & 0.00 & 0.00 & 0.00 & 0.17 \\
\hline Pseuderanthemum riedelianum & 0.43 & 0.57 & 0.50 & 0.00 & 0.00 & 0.00 & 0.00 & 0.00 & 0.00 & 0.17 \\
\hline Campomanesia reitziana* & 0.43 & 0.57 & 0.50 & 0.00 & 0.00 & 0.00 & 0.00 & 0.00 & 0.00 & 0.17 \\
\hline Psychotria deflexa & 0.43 & 0.57 & 0.50 & 0.00 & 0.00 & 0.00 & 0.00 & 0.00 & 0.00 & 0.17 \\
\hline Justicia carnea & 0.43 & 0.57 & 0.50 & 0.00 & 0.00 & 0.00 & 0.00 & 0.00 & 0.00 & 0.17 \\
\hline Miconia cinerascens var. robusta & 0.00 & 0.00 & 0.00 & 0.00 & 0.00 & 0.00 & 0.57 & 0.28 & 0.43 & 0.14 \\
\hline Cariniana estrellensis & 0.00 & 0.00 & 0.00 & 0.36 & 0.47 & 0.41 & 0.00 & 0.00 & 0.00 & 0.14 \\
\hline Inga sp. & 0.00 & 0.00 & 0.00 & 0.36 & 0.47 & 0.41 & 0.00 & 0.00 & 0.00 & 0.14 \\
\hline Inga vera subsp. affinis & 0.00 & 0.00 & 0.00 & 0.36 & 0.47 & 0.41 & 0.00 & 0.00 & 0.00 & 0.14 \\
\hline Casearia sylvestris & 0.00 & 0.00 & 0.00 & 0.36 & 0.47 & 0.41 & 0.00 & 0.00 & 0.00 & 0.14 \\
\hline Syzygium jambos ${ }^{* *}$ & 0.00 & 0.00 & 0.00 & 0.36 & 0.47 & 0.41 & 0.00 & 0.00 & 0.00 & 0.14 \\
\hline Myrciaria floribunda* & 0.00 & 0.00 & 0.00 & 0.36 & 0.47 & 0.41 & 0.00 & 0.00 & 0.00 & 0.14 \\
\hline Campomanesia xanthocarpa & 0.00 & 0.00 & 0.00 & 0.36 & 0.47 & 0.41 & 0.00 & 0.00 & 0.00 & 0.14 \\
\hline Brosimum glaziovii* & 0.00 & 0.00 & 0.00 & 0.36 & 0.47 & 0.41 & 0.00 & 0.00 & 0.00 & 0.14 \\
\hline Calyptranthes lucida & 0.00 & 0.00 & 0.00 & 0.36 & 0.47 & 0.41 & 0.00 & 0.00 & 0.00 & 0.14 \\
\hline Copaifera trapezifolia & 0.00 & 0.00 & 0.00 & 0.36 & 0.47 & 0.41 & 0.00 & 0.00 & 0.00 & 0.14 \\
\hline Erythroxylum cuspidifolium & 0.00 & 0.00 & 0.00 & 0.00 & 0.00 & 0.00 & 0.19 & 0.28 & 0.24 & 0.08 \\
\hline Marlierea eugeniopsoides & 0.00 & 0.00 & 0.00 & 0.00 & 0.00 & 0.00 & 0.19 & 0.28 & 0.24 & 0.08 \\
\hline Cordiera concolor & 0.00 & 0.00 & 0.00 & 0.00 & 0.00 & 0.00 & 0.19 & 0.28 & 0.24 & 0.08 \\
\hline Cryptocarya aschersoniana & 0.00 & 0.00 & 0.00 & 0.00 & 0.00 & 0.00 & 0.19 & 0.28 & 0.24 & 0.08 \\
\hline Bactris setosa & 0.00 & 0.00 & 0.00 & 0.00 & 0.00 & 0.00 & 0.19 & 0.28 & 0.24 & 0.08 \\
\hline Geonoma gamiova* & 0.00 & 0.00 & 0.00 & 0.00 & 0.00 & 0.00 & 0.19 & 0.28 & 0.24 & 0.08 \\
\hline Psychotria carthagenensis & 0.00 & 0.00 & 0.00 & 0.00 & 0.00 & 0.00 & 0.19 & 0.28 & 0.24 & 0.08 \\
\hline Ocotea nectandrifolia* & 0.00 & 0.00 & 0.00 & 0.00 & 0.00 & 0.00 & 0.19 & 0.28 & 0.24 & 0.08 \\
\hline
\end{tabular}

$\mathrm{RD} 1$ = relative density for Class 1; RF1 = relative frequency for Class 1; NRI1 = Natural Regeneration Index for Class 1; RD2 = relative density for Class 2; RF2 = relative frequency for Class 2; NRI2 = Natural Regeneration Index for Class 2; RD3 = relative density for Class 3; RF3 = relative frequency for Class 3; NRI3 = Natural Regeneration Index for Class 3; NRI = total Natural Regeneration Index. ${ }^{*}$ threatened species according to Martinelli \& Moraes (2013); ${ }^{* *}$ exotic species. 
Table 1. Continued...

\begin{tabular}{|c|c|c|c|c|c|c|c|c|c|c|}
\hline \multirow{2}{*}{ Species } & \multicolumn{3}{|c|}{ Class 1} & \multicolumn{3}{|c|}{ Class 2} & \multicolumn{3}{|c|}{ Class 3} & \multirow{2}{*}{ NRI } \\
\hline & RD1 & RF1 & NRI1 & RD2 & RF2 & NRI2 & RD3 & RF3 & NRI3 & \\
\hline Jacaranda puberula & 0.00 & 0.00 & 0.00 & 0.00 & 0.00 & 0.00 & 0.19 & 0.28 & 0.24 & 0.08 \\
\hline Aniba firmula & 0.00 & 0.00 & 0.00 & 0.00 & 0.00 & 0.00 & 0.19 & 0.28 & 0.24 & 0.08 \\
\hline Tapirira guianensis & 0.00 & 0.00 & 0.00 & 0.00 & 0.00 & 0.00 & 0.19 & 0.28 & 0.24 & 0.08 \\
\hline Coffea arabica ${ }^{* *}$ & 0.00 & 0.00 & 0.00 & 0.00 & 0.00 & 0.00 & 0.19 & 0.28 & 0.24 & 0.08 \\
\hline Amaioua guianensis & 0.00 & 0.00 & 0.00 & 0.00 & 0.00 & 0.00 & 0.19 & 0.28 & 0.24 & 0.08 \\
\hline Psychotria vellosiana & 0.00 & 0.00 & 0.00 & 0.00 & 0.00 & 0.00 & 0.19 & 0.28 & 0.24 & 0.08 \\
\hline Endlicheria paniculata & 0.00 & 0.00 & 0.00 & 0.00 & 0.00 & 0.00 & 0.19 & 0.28 & 0.24 & 0.08 \\
\hline Aparisthmium cordatum & 0.00 & 0.00 & 0.00 & 0.00 & 0.00 & 0.00 & 0.19 & 0.28 & 0.24 & 0.08 \\
\hline Miconia budlejoides & 0.00 & 0.00 & 0.00 & 0.00 & 0.00 & 0.00 & 0.19 & 0.28 & 0.24 & 0.08 \\
\hline Total & & & 100.00 & & & & 100.00 & & 100.00 & 100.00 \\
\hline
\end{tabular}

$\mathrm{RD} 1=$ relative density for Class $1 ; \mathrm{RF} 1=$ relative frequency for Class $1 ; \mathrm{NRI} 1=$ Natural Regeneration Index for Class $1 ; \mathrm{RD} 2=$ relative density for Class 2; RF2 = relative frequency for Class 2; NRI2 = Natural Regeneration Index for Class 2; RD3 = relative density for Class 3; RF3 = relative frequency for Class 3; NRI3 = Natural Regeneration Index for Class 3; NRI = total Natural Regeneration Index. ${ }^{\star}$ threatened species according to Martinelli \& Moraes (2013); ${ }^{* *}$ exotic species.
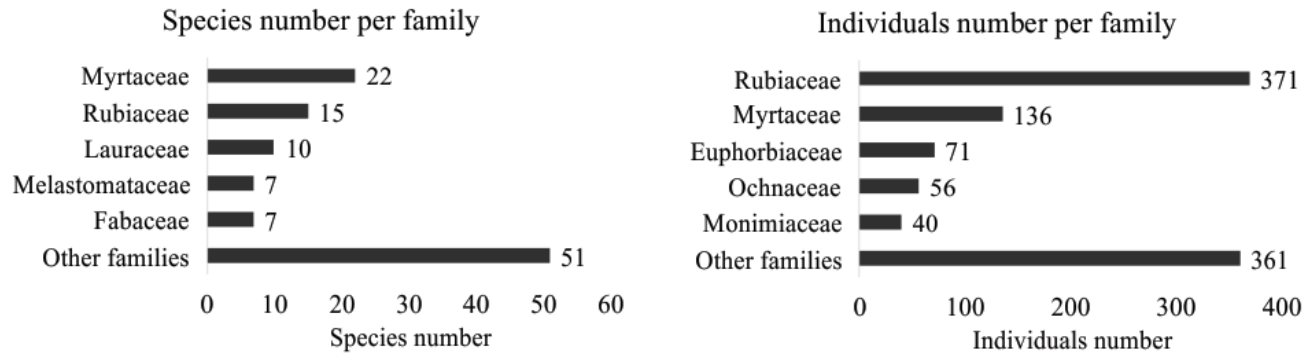

Figure 1. Species and individual numbers per family sampled in natural regeneration component at SFAMNP, Blumenau/SC.

The most abundant species were Rudgea recurva (149 ind.), R. jasminoides (84 ind.), Psychotria nuda (63 ind.), Ouratea parviflora (56 ind.), and Marlierea tomentosa (48 ind.), corresponding to $38.65 \%$ of the total individuals sampled. We sampled 18 threatened species, and we also found two exotic species in the sample, the coffee tree (Coffea arabica) and pink jambo (Syzygium jambos, Table 1).

The species that obtained the highest values in the Natural Regeneration Index (NRI) were: Rudgea recurva (11.28\%), Rudgea jasminoides (7.53\%), Psychotria nuda (5.51\%), Ouratea parviflora (4.86\%), Marlierea tomentosa (4.08\%), Virola bicuhyba (3.89\%), Mollinedia schottiana (3.46\%), Sorocea bonplandii (3.32\%), Dendropanax australis (3.31\%) and Margaritopsis astrellantha $(2.74 \%)$. These species represented $52.53 \%$ of the NRI sampled (Table 1).
Regarding the species ecological groups, $16.07 \%$ corresponded to pioneer (with 5.7\% of individuals), $48.21 \%$ as secondary (39.81\% of individuals) and $28.57 \%$ as climax (52.85\% of individuals), with $7.14 \%$ being unable to be classified ( $1.64 \%$ of individuals) (Table 2). The tree life-form was comprised of $45.54 \%$ of species and $21.64 \%$ of individuals, treelets with $31.25 \%$ of species and $51.5 \%$ of individuals, shrubs with $16.96 \%$ of species and $24.35 \%$ of individuals, sub-bushes $3.57 \%$ of species and $1.74 \%$ of individuals, and palm with $2.68 \%$ of species and $0.77 \%$ of individuals.

The species accumulation curve tended to be stable (Figure 2). The Shannon diversity and Pielou equability indices for each size class are shown in Table 3 , in which Classes 1 and 2 presented the highest $H^{\prime}$ value, while Class 2 presented the highest J value. 
Table 2. Species and individuals by ecological group and life-form for each class in natural regeneration component at SFAMNP, Blumenau/SC.

\begin{tabular}{|c|c|c|c|c|c|c|c|c|c|}
\hline & \multicolumn{2}{|c|}{ Class 1} & \multicolumn{2}{|c|}{ Class 2} & \multicolumn{2}{|c|}{ Class 3} & \multicolumn{2}{|c|}{ Total } \\
\hline & & Species & Ind. & Species & Ind. & Species & Ind. & Species & Ind. \\
\hline \multirow{4}{*}{$\begin{array}{l}\text { Ecological } \\
\text { groups }\end{array}$} & Climax & 24 & 112 & 23 & 141 & 26 & 294 & 32 & 547 \\
\hline & Secondary & 31 & 90 & 33 & 119 & 38 & 203 & 54 & 412 \\
\hline & Pioneer & 9 & 24 & 7 & 12 & 11 & 23 & 18 & 59 \\
\hline & Non-classified & 4 & 8 & 4 & 7 & 2 & 2 & 8 & 17 \\
\hline \multirow{5}{*}{ Life-forms } & Tree & 28 & 66 & 34 & 64 & 32 & 94 & 51 & 224 \\
\hline & Treelet & 19 & 89 & 21 & 145 & 28 & 299 & 35 & 533 \\
\hline & Shrub & 16 & 58 & 10 & 68 & 14 & 126 & 19 & 252 \\
\hline & Sub-bush & 4 & 18 & 0 & 0 & 0 & 0 & 4 & 18 \\
\hline & Palm & 1 & 3 & 1 & 2 & 3 & 3 & 3 & 8 \\
\hline
\end{tabular}

Legend: Ind. = individuals.
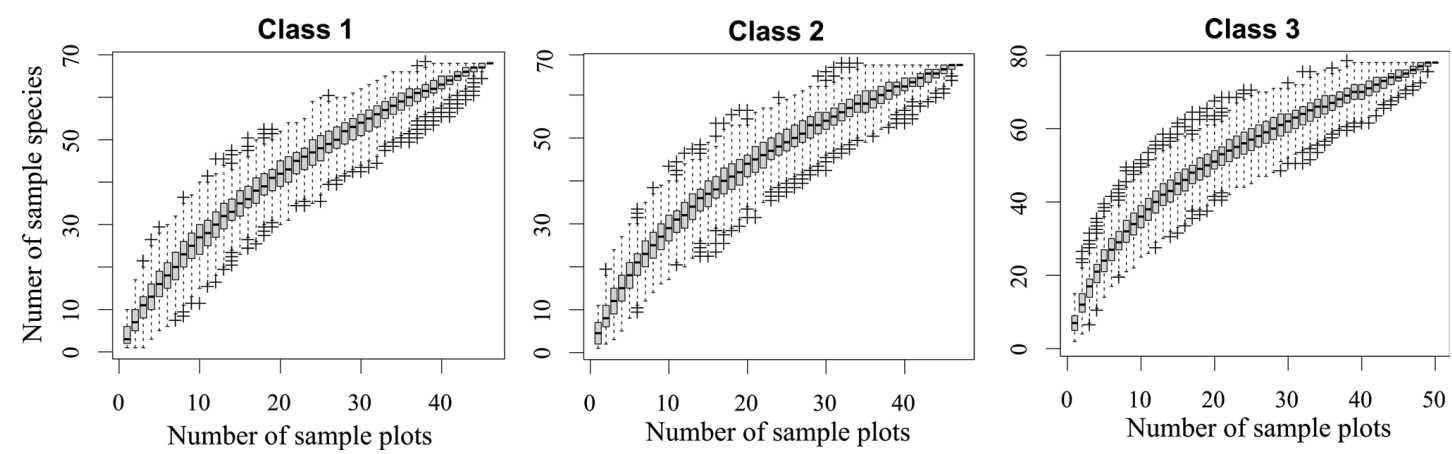

Figure 2. Species accumulation curve for each class in natural regeneration component at SFAMNP, Blumenau/SC.

Table 3. Species, genera, families, Shannon and Pielou indexes, individuals per hectare and effective sample plots for each class in natural regeneration component at SFAMNP, Blumenau/SC.

\begin{tabular}{lccc} 
& Class 1 & Class 2 & Class 3 \\
Species & 68 & 67 & 77 \\
Genera & 43 & 49 & 54 \\
Families & 28 & 29 & 29 \\
Shannon Index & 3.61 & 3.61 & 3.47 \\
Pielou Index & 0.855 & 0.858 & 0.797 \\
Ind/ha & $5,200.00$ & $6,177.78$ & $4,184.00$ \\
\hline Effective sample plots & 46 & 47 & 50 \\
\hline
\end{tabular}

\section{DISCUSSION}

\subsection{Floristic composition}

The first five richest families in this study were the same for all Subtropical Rain Forest in Santa Catarina (Meyer et al., 2013). These five families, in addition to Euphorbiaceae, are the most important for the Subtropical Rain Forest in Brazil (Oliveira-Filho \& Fontes, 2000).
Myrtaceae, which presented the greatest richness in this study, is considered the fourth richest botanical family in Brazil, standing out as one of the dominant families in several vegetation formations (Landrum \& Kawasaki, 1997; Giulietti et al., 2005). The species of this family are ecologically important for the Atlantic Rainforest, presenting diverse relationships to the local fauna, such as pollinator insects like bees and fruit dispersers such as birds, rodents and monkeys (Barroso et al., 1999).

The genera Piper, Psychotria and Miconia are predominantly understory species, whereas Eugenia and Ocote $a$ are present in both understory and canopy (Meyer et al., 2013). Oliveira-Filho \& Fontes (2000) pointed out that Eugenia, Ocotea, Myrcia and Miconia represent the genera with the highest species richness for the Atlantic Forest of Southeastern Brazil. The same pattern was found (except for Myrcia) in the regeneration sample in this study.

Regarding the exotic species found, Carvalho (2005) studied the pink jambo's potential for invasion in a forest fragment in the state of Rio de Janeiro. He found that 
the species have all the characteristics of a successful invasive plant such as short intervals of phenological events, rapid germination and seedling growth. The coffee tree, in turn, is considered invasive, being found in the understories of forests in several regions of Brazil, mainly in the Southeast (Martins et al., 2008).

The predominance of climax and secondary individuals in natural regeneration areas indicates that the forest is in the advanced stages of secondary succession and in a good state of conservation, with an abundant presence of characteristic species from primary forest understories, such as Rudgea spp. and Psychotria spp. (Delprete et al., 2004). The high number of secondary species sampled may indicate old wood exploitation activities and land use in the area, reflecting the current process of regeneration.

The presence of species of different ecological groups in the natural regeneration allows the response of different environmental conditions in the forest, which represent an important colonization mechanism of the area (Sccoti et al., 2011). Pioneer individuals in forests are related to the opening of natural clearings by the falling of trees (Colonetti et al., 2009), which is also considered a mechanism to maintain the diversity of species in tropical forests (Hartshorn, 1980). In the study area, this opening could also be generated by the landslides from 2008, or the severe winter with frost during 2013. Pioneering plants tend to have their regeneration niche associated with' disturbance and are determined by luminosity, acting directly on the recruitment of these species (Goodale et al., 2012). This may be the case of pioneer species sampled in this study, such as Jacaranda puberula, Miconia cabucu and $M$. cinerascens var. robusta.

Species dwelling in the sub-canopy and understory, in conditions of the interior of the forest, do not determine the physiognomy of the community canopy, but rather the internal vertical strata of the community, with trees and emergent individuals composing the physiognomy of the canopy (Sevegnani, 2003). Thus, natural regeneration is effectively represented by trees and palms, corresponding to young individuals of canopy species (Meyer et al., 2013). Rubiaceae, Melastomataceae and Piperaceae represent species of other life-forms, which are presented mainly by treelets and shrubs that have their ecological niche only in the understory (Meyer et al., 2013).
These natural regeneration sinusia, in the Atlantic Forest, are composed of a relatively small number of species, but with a large number of individuals (Veloso \& Klein, 1957). In this study, the tree group consisted of $45.54 \%$ of the species and $21.64 \%$ of the individuals in the natural regeneration, while the shrubs contributed only $16.96 \%$ of the species, and therefore $24.35 \%$ of the individuals, represented mainly by Psychotria nuda (6.09\% of individuals), Ouratea parviflora (5.41\% of individuals), and Dendropanax australis (3.28\% of individuals).

The Shannon diversity and Pielou equability indices for each size class indicate high biological diversity of natural regeneration, as well as high equability among species. Meyer et al. (2013) warns that high diversity indexes do not necessarily suggest that the forest presents well-preserved vegetation, depending on the action of degradation factors such as brushing in the understories and selective cutting of tree species, influencing the composition and richness of natural regeneration. The park underwent selective logging with some areas subjected to clear cutting of the forest and land use for cultivation. However, the area has since gone more than 50 years without exploitation (Sevegnani, 2003).

\subsection{Natural regeneration structure}

$R$. recurva and $R$. jasminoides had the highest NRI in all size classes. Both species are typical of sub-forests of primary forests in the Subtropical Rain Forest (Delprete et al., 2004). Tabarelli \& Mantovani (1997) cite that many understory species may occur in secondary forests of different ages, as well as, in old forests with different structures. This pattern indicates a broad niche of regeneration, observed by the authors in R. jasminoides. This phenomenon may explain its high regeneration in this study, suggesting that these species have the potential to regenerate in several environments.

Rubiaceae represented $32.05 \%$ of the NRI obtained in this study, highlighting the family importance of the understory structure in sub-tropical forests, and establishing important ecological relationships. This family provides resources such as pollen, nectar and fruits to birds, mammals, and insects (Citadini-Zanette et al., 2009; Paiva et al., 2016). On the other hand, Myrtaceae, which presented the highest richness value in this study, corresponded to $14.03 \%$ of the NRI sampled. 
Species that have NRI indexes below 1.0\% may, from a given time, demonstrate a higher degree of difficulty in regenerating, or suggest that late species are establishing themselves in the ecosystem (Silva et al., 2010). In the present study, 89 species obtained values lower than $1.0 \%$ for NRI, of which 44 are secondary species and 17 are pioneers. Therefore, low regeneration of these species may be associated with environmental conditions, where canopy closure provides microclimatic conditions favorable to shade tolerant species (Higuchi et al., 2006), thereby limiting the establishment of pioneer and secondary species.

With respect to the density of individuals by size class, Class 2 grouped the highest value (Table 3 ). The result obtained did not correspond to the distribution pattern of the individuals in inverted 'J', characterized by the greater number of individuals concentrated in the smaller size classes. Low adult densities and regenerants of a given species suggest that they may be substituted, during forest succession, and in situ conservation will depend on the establishment of all stages of the species growth in the environment (Silva et al., 2004). Likewise, considering the natural regeneration component, species occurring in all size classes in the community will probably form the future structural composition of the forest (Citadini-Zanette, 1995).

Thus, according to the results of this study (and not considering the seed bank), species such as Cryptocarya aschersoniana, Plinia cordifolia, Ocotea catharinensis, and Copaifera trapezifolia, among others, presented low NRI values and no individuals were reported in the smallest size class, indicating the possible absence of these species in the future forest composition. However, Schaaf et al. (2006) postulates that if even a species has few individuals in the smaller classes, but is subjected to a low probability of dying due to competition, the chance of these species remaining in the environment is high.

\section{CONCLUSION}

The families Myrtaceae, Rubiaceae, Lauraceae and Melastomataceae, as well as the genera Eugenia, Psychotria, Miconia and Ocotea constitute the richest taxa. The most abundant species were Rudgea recurva and $R$. jasminoides, typical of understory and very frequent in the Santa Catarina Subtropical Rain Forest, demonstrating their importance in structuring the forest.
The results indicated a natural regeneration component with high diversity, equability and characteristic elements of the primary forests in the Atlantic Forest.

The secondary species presented a greater number of species, followed by the climax ones and finally the pioneers. However, the climax species were more abundant, followed by the secondary ones and pioneers. The treelet life-form was predominant among the individuals, whereas the arboreal life-form comprised the largest number of species.

The natural regeneration represented mainly by the species Rudgea recurva, R. jasminoides, Ouratea parviflora, Psychotria nuda and Virola bicuhyba, evidenced their regeneration potential. However, 89 of the 112 species sampled presented low regeneration, half of which were secondary. The understory microclimatic conditions may limit the regeneration of these species, and simultaneously favor species from more advanced succession stages.

We observed species with low regeneration, with few or no individuals present in the smaller size classes, indicating a tendency to be substituted in future forest composition. We suggest continuous monitoring of these species in the Park area and the elaboration of an adequate management plan that allows these measures.

\section{ACKNOWLEDGEMENTS}

The authors are grateful to the Universidade Regional de Blumenau (FURB) for providing support, and to the anonymous reviewers for their valuable comments that helped to improve the manuscript. We would also like to thank Marta Caetano (FURB Idiomas) for reviewing the English translation, and to Parque Natural Municipal São Francisco de Assis Municipal for providing the opportunity to realize this study.

\section{SUBMISSION STATUS}

Received: 17 aug., 2017

Accepted: 22 nov., 2017

\section{CORRESPONDENCE TO}

\section{Fábio Pastório}

Rua Antônio da Veiga, 140, Victor Konder, CEP 89012-900, Blumenau, SC, Brasil e-mail: fiamoncini.f@gmail.com 


\section{FINANCIAL SUPPORT}

$\mathrm{CNPq}$ (Conselho Nacional de Desenvolvimento Científico e Tecnológico) - PIBIC (Programa Institucional de Bolsas de Iniciação Científica).

\section{REFERENCES}

Amador DB, Viana VM. Dinâmica de "capoeiras baixas" na restauração de um fragmento florestal. Scientia Forestalis 2000; 57: 69-85.

Araújo MM, Longhi SJ, Barros PLC, Brena DA. Caracterização da chuva de sementes, banco de sementes do solo e banco de plântulas em Floresta Estacional Decidual Ripária Cachoeira do Sul, RS, Brasil. Scientia Forestalis 2004; 66: 128-141.

Barroso GM, Morin MP, Peixoto AL, Ichaso CLF. Frutose sementes: morfologia aplicada à sistemática de dicotiledôneas. Viçosa: Editora UFV; 1999.

Carvalho FA. Syzygium jambos (L.) Alston: uma invasora na Mata Atlântica? In: Simpósio Brasileiro de espécies exóticas e invasoras. Brasília: Ministério do Meio Ambiente; 2005. p. 13.

Citadini-Zanette V, Delfino RF, Brum-Figueiró AC, \& Santos, R. Rubiaceae na recuperação ambiental no sul de Santa Catarina. Revista de Estudos Ambientais 2009; 11(1): 71-82.

Citadini-Zanette V. Florística, fitossociologia e aspectos da dinâmica de um remanescente de Mata Atlântica na microbacia do rio novo, Orleans, SC [tese]. São Carlos: Universidade Federal de São Carlos; 1995.

Colonetti S, Citadini-Zanette V, Martins R., Santos R., Rocha E, Jarenkow JA. Florística e estrutura fitossociológica em floresta ombrófila densa submontana na barragem do rio São Bento, Siderópolis, Estado de Santa Catarina. Maringá 2009; 31(4): 387-405.

Delprete P, Smith LB, Klein RM. Rubiáceas. In: Reitz R, Reis A, editors. Flora Ilustrada Catarinense. Itajaí: Herbário Barbosa Rodrigues; 2004.

Fenner M, Thompson K. The ecology of seeds. Cambridge: University Press; 2005. http://dx.doi.org/10.1017/ CBO9780511614101.

Finol UH. Nuevos parametros a considerarse en el analisis estrutural de las selvas virgenes tropicales. Revista Forestal Venezolana 1971; 18(12): 29-42.

Garwood NC. Tropical soil seed banks: a review. In: Leck MA, Parker VT, Simpson RL, editors. Ecology of soil seed banks. San Diego: Academic Press; 1989. http://dx.doi. org/10.1016/B978-0-12-440405-2.50014-2.

Giulietti AM, Harley RM, De Queiroz LP, Wanderley MGL, Van Den Berg C. Biodiversity and conservation of plants in Brazil. Conservation Biology 2005; 19(3): 632639. http://dx.doi.org/10.1111/j.1523-1739.2005.00704.x.

Goodale UM, Ashton MS, Berlyn GP, Gregoire TG, Singhakumara BMP, Tennakoon KU. Disturbance and tropical pioneer species: Patterns of association across life history stages. Forest Ecology and Management 2012; 277: 54-66. http://dx.doi.org/10.1016/j.foreco.2012.04.020.

Hanazaki N. Comunidades, conservação e manejo: o papel do conhecimento ecológico local. Biotemas 2003; 16(1): 23-47.

Hartshorn GS. Neotropical forest dynamics. Biotropica 1980; 12(2): 30-32. http://dx.doi.org/10.2307/2388152.

Higuchi P, Reis MGF, Reis GG, Pinheiro AL, Silva CT, Oliveira CHR. Composição florística da regeneração natural de espécies arbóreas ao longo de oito anos em um fragmento de floresta estacional semidecidual, em Viçosa, MG. Revista Árvore 2006; 30(6): 893-904. http:// dx.doi.org/10.1590/S0100-67622006000600004.

Instituto Brasileiro do Meio Ambiente e dos Recursos Naturais Renováveis - IBAMA. Instrução Normativa $n$. 4 de 04/03/02. Brasília; 2002, 31p.

Koeppen W. Climatologia. México: Fondo de Cultura; 1948.

Landrum LR, Kawasaki ML. The genera of Myrtaceae in Brazil - an illustrated synoptic treatment and identification keys. Brittonia 1997; 49(4): 508-536. http://dx.doi. org/10.2307/2807742.

Lingner DV, Schorn LA, Vibrans AC, Meyer L, Sevegnani L, Gasper AL et al. Fitossociologia do componente arbóreo/ arbustivo da Floresta Ombrófila Densa no Estado de Santa Catarina. In: Vibrans AC, Sevegnani L, Gasper $\mathrm{AL}$, Lingner DV, editors. Inventário Florístico Florestal de Santa Catarina, Vol. IV, Floresta Ombrófila Densa. Blumenau: Edifurb; 2013.

Magurran AE. Ecological diversity and its measurement. Princeton: Princeton University Press; 1988. http://dx.doi. org/10.1007/978-94-015-7358-0.

Martinelli G, Moraes MA. Livro Vermelho da Flora do Brasil. 1. ed. Rio de Janeiro: Instituto de Pesquisas Jardim Botânico do Rio de Janeiro; 2013

Martins SV, Gleriani JM, Amaral CH, Ribeiro TM. Caracterização do dossel e do estrato de regeneração natural no sub-bosque e em clareiras de uma floresta estacional semidecidual no município de Viçosa, MG. Revista Árvore 2008; 32(4): 759-767. http://dx.doi. org/10.1590/S0100-67622008000400018.

Melo FPL. Recrutamento e estabelecimento de Plântulas. In: Ferreira AG, Borghetti F, editors. Germinação: do básico ao aplicado. Porto Alegre: Artmed; 2004.

Metzger JP. Tree functional group richness and landscape structure in a Brazilian tropical fragmented landscape. Ecological Applications 2000; 10(4): 1147-1161. http:// dx.doi.org/10.1890/1051-0761(2000)010[1147:TFGRA L]2.0.CO;2. 
Meyer L, Gasper AL, Sevegnani L, Schorn LA, Vibrans AC, Lingner DV et al. Regeneração natural da Floresta Ombrófila Densa em Santa Catarina. In: Vibrans AC, Sevegnani L, Gasper AL, Lingner DV, editors. Inventário Florístico Florestal de Santa Catarina, Vol. IV, Floresta Ombrófila Densa. Blumenau: Edifurb; 2013.

Ministério do Meio Ambiente. Secretaria de Biodiversidade e Florestas. Áreas Prioritárias para Conservação, Uso Sustentável e Repartição de Benefícios da Biodiversidade Brasileira: Atualização - Portaria $M M A n^{\circ} 9$, de 23 de janeiro de 2007. Brasília: MMA. 2007. (Série Biodiversidade; no. 31)

Narvaes IS, Longhi SJ, Brena DA. Florística e classificação da regeneração natural em Floresta Ombrófila Mista na Floresta Nacional de São Francisco de Paula, RS. Ciência Florestal 2008; 18(2): 233-245. http://dx.doi. org/10.5902/19805098460.

Oliveira-Filho AT, Fontes MAL. Patterns of floristic differentiation among Atlantic forests in southeastern Brazil, and the influence of climate. Biotropica 2000; 32(4b): 793-810. http://dx.doi.org/10.1111/j.1744-7429.2000. tb00619.x.

Paiva AM, Barberena FFVA, Lopes RC. Rubiaceae in Brazilian Atlantic Forest remnants: floristic similarity and implications for conservation. Revista de Biología Tropical 2016; 64(2): 655-665. http://dx.doi.org/10.15517/ rbt.v64i2.19087. PMid:29451761.

Pinto LP, Bedê L, Paese A, Fonseca M, Paglia A, Lamas I. Mata Atlântica Brasileira: os desafios para conservação da biodiversidade de um hotspot mundial. In: Rocha CFD, Bergallo HG, Van Sluys M, Alves MAS, editors. Biologia da Conservação: essências. São Carlos: RiMa; 2006.

R Development Core Team. R: a language and environment for statistical computing [online]. Vienna: R Foundation for Statistical Computing. 2017 [cited 2017 Feb 22]. Available from: http://www.R-project.org

Ribeiro MC, Metzger JP, Martensen AC, Ponzoni FJ, Hirota MM. The Brazilian Atlantic Forest: how much is left, and how is the remaining forest distributed? Implications for conservation. Biological Conservation 2009; 142(6): 1141 1153. http://dx.doi.org/10.1016/j.biocon.2009.02.021.
Sccoti MSV, Araujo MM, Wendler CF, Longhi SJ. Mecanismos de regeneração natural em remanescente de Floresta Estacional Decidual. Ciência Florestal 2011; 21(3): 459-472. http://dx.doi.org/10.5902/198050983803.

Schaaf LB, Figueiredo Filho A, Galvão F, Sanquetta CR. Alteração na estrutura diamétrica de uma floresta ombrófila mista no período entre 1979 e 2000. Revista Árvore 2006; 30(2): 283-295. http://dx.doi.org/10.1590/ S0100-67622006000200016.

Schorn LA, Galvão F. Dinâmica da regeneração natural em três estágios sucessionais de uma Floresta Ombrófila Densa em Blumenau, SC. Revista Floresta 2006; 36(1): 59-74.

Sevegnani L. Dinâmica de população de Virola bicuhyba (Schott) Warb. (Myristicaceae) e Fitossociologia de Floresta Pluvial Atlântica, sob clima temperado, Blumenau, SC [tese]. São Paulo: Instituto de Biociências, Universidade de São Paulo; 2003.

Silva JA, Leite EJ, Nascimento ART, Rezende JMD. Distribuição diamétrica de indivíduos de Aspidospema spp. na Reserva Genética Tamanduá, DF [online]. Brasília: Embrapa; 2004. [cited 2016 jun. 20]. (Comunicado Técnico; no. 119) Available from: http://www.infoteca. cnptia.embrapa.br/bitstream/doc/185712/1/cot119.pdf.

Silva WC, Marangon LC, Ferreira RLC, Feliciano ALP, Aparício PS, Costa RF Jr. Estrutura horizontal e vertical do componente arbóreo em fase de regeneração natural da mata Santa Luzia, no município de Carende-PE. Revista Árvore 2010; 34(5): 863-869. http://dx.doi.org/10.1590/ S0100-67622010000500011.

Tabarelli M, Mantovani W. Colonização de clareiras naturais na floresta atlântica no sudeste do Brasil. Brazilian Journal of Botany 1997; 20(1): 57-66. http://dx.doi.org/10.1590/ S0100-84041997000100006.

Veloso HP, Klein RM. As comunidades e associações vegetais da mata pluvial do sul do Brasil. I. As comunidades do Mun. de Brusque, SC. Sellowia 1957; 9: 81-235.

Volpato MML. Regeneração natural em uma floresta secundária no domínio de Mata Atlântica: uma análise fitossociológica [dissertação]. Viçosa: Universidade Federal de Viçosa; 1994. 